Article

\title{
Terminalia bellirica Extract Inhibits Low-Density Lipoprotein Oxidation and Macrophage Inflammatory Response in Vitro
}

\author{
Miori Tanaka ${ }^{1}$, Yoshimi Kishimoto ${ }^{2, *}$, Emi Saita ${ }^{2}$, Norie Suzuki-Sugihara ${ }^{1}$, \\ Tomoyasu Kamiya ${ }^{3}$, Chie Taguchi ${ }^{2}$, Kaoruko Iida ${ }^{1}$ and Kazuo Kondo ${ }^{2,4}$ \\ 1 Department of Food and Nutritional Sciences, Graduate School of Humanities and Sciences, \\ Ochanomizu University, 2-1-1 Otsuka, Bunkyo-ku, Tokyo 112-8610, Japan; \\ g1670502@edu.cc.ocha.ac.jp (M.T.); notch0708@gmail.com (N.S.-S.); iida.kaoruko@ocha.ac.jp (K.I.) \\ 2 Endowed Research Department "Food for Health", Ochanomizu University, 2-1-1 Otsuka, Bunkyo-ku, \\ Tokyo 112-8610, Japan; saita.emi@ocha.ac.jp (E.S.); taguchi.chie@ocha.ac.jp (C.T.); \\ kondo.kazuo@ocha.ac.jp (K.K.) \\ 3 Research and Development Division, Toyo Shinyaku Co Ltd., 7-28 Yayoigaoka, Tosu-shi, Saga 841-0005, \\ Japan; kamiyat@toyoshinyaku.co.jp \\ 4 Institute of Life Innovation Studies, Toyo University, 1-1-1 Izumino, Itakura-machi, Ora-gun, \\ Gunma 374-0193, Japan \\ * Correspondence: kishimoto.yoshimi@ocha.ac.jp; Tel.: +81-3-5978-5810; Fax: +81-3-5978-2694
}

Academic Editor: Steven P. Gieseg

Received: 16 May 2016; Accepted: 7 June 2016; Published: 14 June 2016

\begin{abstract}
The deciduous tree Terminalia bellirica found in Southeast Asia is extensively used in traditional Indian Ayurvedic medicine for the treatment of hypertension, rheumatism, and diabetes. The anti-atherogenic effect of Terminalia bellirica fruit has not been fully elucidated. Here, we investigated the effect of Terminalia bellirica extract (TBE) on low-density lipoprotein (LDL) oxidation and inflammation in macrophages. TBE showed 1,1-diphenyl-2-picrylhydrazyl (DPPH) radical scavenging activity $\left(\mathrm{EC}_{50}: 7.2 \pm 1.2 \mu \mathrm{g} / \mathrm{mL}\right)$ and 15-lipoxygenase inhibitory activity. TBE also significantly inhibited free radical-induced LDL oxidation compared to the solvent control in vitro. In THP-1 macrophages, TBE treatment resulted in significant decreases of the mRNA expression of tumor necrosis factor-alpha (TNF- $\alpha$ ), interleukin-1beta (IL-1 $\beta$ ), and lectin-like oxidized LDL receptor-1 (LOX-1). TBE also reduced matrix metalloproteinase (MMP)-9 secretion and intracellular reactive oxygen species (ROS) production in THP-1 macrophages. These results show that TBE has the inhibitory effects on LDL oxidation and macrophage inflammatory response in vitro, suggesting that its in vivo use might inhibit atherosclerosis plaque progression.
\end{abstract}

Keywords: Terminalia bellirica; polyphenol; lipid oxidation; macrophage; inflammation; atherosclerosis

\section{Introduction}

Terminalia bellirica is a deciduous tree that is common in Southeast Asia. In traditional Indian Ayurvedic medicine, the fruit of Terminalia bellirica is extensively used as a folk medicine for the treatments of diabetes, hypertension, and rheumatism [1]. The major polyphenolic components of the fruit are reported to be gallic acid, ellagic acid, and chebulagic acid [2]. Terminalia bellirica extract (TBE), which is obtained from the fruit of Terminalia bellirica, has been reported to show hypolipidemic [3], hypoglycemic [4], and antihypertensive [5] properties in mice and in human subjects, and it is used as a dietary supplement.

Atherosclerosis, a major cause of death, is highly associated with the oxidative modification of low-density lipoprotein (LDL) and inflammation in the vascular wall. Oxidized LDL (oxLDL), which 
is detected in atherosclerotic lesions, is considered to be one of the main risk factors for atherosclerosis. Foam cell formation is mainly due to an uninterrupted uptake of oxLDL in macrophages, resulting in an excessive level of lipoprotein-derived cholesterol accumulation in the intima [6]. Scavenger receptors (e.g., class A scavenger receptor (SR-A), CD36, and lectin-like oxLDL receptor-1 (LOX-1)) are responsible for the uptake of modified LDL by macrophages [7]. In addition, oxLDL activates the cascade of local inflammation in the vascular wall by upregulating the expression of adhesion molecules, growth factors, and pro-inflammatory cytokines [8].

The macrophage-mediated inflammatory response plays a crucial role in the progression of atherosclerosis. In atherosclerotic lesions, macrophages release pro-inflammatory cytokines, reactive oxygen species (ROS), and matrix metalloproteinases (MMPs) [9,10]. Some reports have suggested that ROS may be involved in cell growth, adhesion, and vascular endothelial dysfunction [11-13]. ROS overproduction is associated with the production of many inflammatory mediators and a range of inflammation-related diseases [13]. MMPs, a family of $\mathrm{Zn}^{2+}$-dependent endopeptidases, have been linked to weakening of the vascular wall and plaque rupture due to degradation of the extracellular matrix [14,15]. The modulation of LDL oxidation and inflammation in macrophages would thus be important to therapeutic strategies against atherosclerosis. Dietary antioxidants such as polyphenols have been reported to prevent LDL oxidation [16,17] and inflammatory response in macrophages [18]. A negative correlation between polyphenol consumption and cardiovascular disease has been revealed by a number of epidemiologic studies [19-21].

TBE is known to contain polyphenols that have an antioxidant property. However, there is little information about the effects of TBE regarding the prevention of atherosclerosis. The aim of this study was to determine whether TBE has an antioxidant effect on LDL oxidation and whether it inhibits inflammatory mediator expression in macrophages.

\section{Materials and Methods}

\subsection{Reagents}

A hot water extract of Terminalia bellirica was provided by Toyo Shinyaku Co., Ltd. (Saga, Japan). The powder was dissolved in deionized water and used in the experiments. The contents of gallic acid and ellagic acid in the TBE stock solution $(40 \mathrm{mg} / \mathrm{mL})$ were $4.6 \mathrm{mg} / \mathrm{mL}$ and $0.16 \mathrm{mg} / \mathrm{mL}$, respectively. RPMI-1640 medium, phorbol-12-myristate-13-acetate (PMA), Hank's balanced salts solution (HBSS), and $2^{\prime}, 7^{\prime}$-dichlorofluorescein-diacetate (DCFH-DA) were purchased from Sigma-Aldrich (St. Louis, MO, USA). Fetal bovine serum (FBS) and penicillin/streptomycin were obtained from GIBCO (Life Technologies, Grand Island, NY, USA).

\subsection{Determination of Total Polyphenol Content}

The total polyphenol content was determined by a Folin-Ciocalteu assay, as described in [22]. In brief, the Folin-Ciocalteu phenol reagent (Nacalai Tesque, Kyoto, Japan) was added to the sample and incubated in $1.5 \% \mathrm{Na}_{2} \mathrm{CO}_{3}$ solution for $2 \mathrm{~h}$ at $20^{\circ} \mathrm{C}$, and the absorbance was determined at $750 \mathrm{~nm}$ using a DU800 spectrophotometer (Beckman Coulter, Brea, CA, USA). The results are expressed as a (+)-catechin (Wako Pure Chemicals, Osaka, Japan) equivalent.

\subsection{1,1-Diphenyl-2-Picrylhydrazyl (DPPH) Radical Scavenging Activity}

The free radical scavenging activity was determined using 1,1-diphenyl-2-picrylhydrazyl (DPPH) (Wako Pure Chemicals). An aqueous solution of TBE powder was mixed with $1 \mathrm{~mL}$ of $0.2 \mathrm{mM}$ DPPH in ethanol. After incubation for $20 \mathrm{~min}$ at $37^{\circ} \mathrm{C}$, the absorbance of each solution was measured at $516 \mathrm{~nm}$ using the DU800 spectrophotometer. The concentration of TBE required to cause a 50\% decrease in the absorbance at $516 \mathrm{~nm}$ relative to the control was then calculated. 


\subsection{Isolation of LDL from Human Subjects}

Blood samples from fasting normolipidemic adult volunteers were collected in sodium EDTA-containing tubes. Plasma samples were immediately prepared by centrifugation at $3000 \mathrm{rpm}$ for $15 \mathrm{~min}$ at $4{ }^{\circ} \mathrm{C}$. The LDL was separated by single-spin density gradient ultracentrifugation at 100,000 rpm for $40 \mathrm{~min}$ at $4{ }^{\circ} \mathrm{C}$ using a TLA-100.4 fixed angle-rotor (Beckman Instruments, Fullerton, CA, USA). The LDL protein concentration was determined using a Micro BCA Protein Assay Kit (Pierce Laboratories, Rockford, IL, USA). All volunteers provided informed consent prior to sample collection. The study was conducted in accordance with the Declaration of Helsinki, and the protocol was approved by the Ethics Committee of Ochanomizu University.

\subsection{LDL Lag Time Assay}

We measured the LDL oxidizability as described in [23]. Briefly, the prepared LDL samples (final concentration of protein: $70 \mu \mathrm{g} / \mathrm{mL}$ ) were oxidized with and without TBE by $400 \mu \mathrm{M}$ 2,2-azobis-4-methoxy-2,4-dimethylvaleronitrile (V-70; $\mathrm{AMVN}-\mathrm{CH}_{3} \mathrm{O}$ ). We determined the kinetics of LDL oxidation by monitoring the absorbance of conjugated dienes at $234 \mathrm{~nm}$, using the DU800 spectrophotometer at $4 \mathrm{~min}$ intervals at $37^{\circ} \mathrm{C}$.

\subsection{5-Lipoxygenase Inhibitory Activity}

We tested the 15-lipoxygenase (15-LOX) inhibitory activity of TBE by using a Lipoxygenase Inhibitor Screening Assay Kit (Cayman Chemical, Ann Arbor, MI, USA). First, $90 \mu \mathrm{L}$ of soybean 15-LOX enzyme solution and $10 \mu \mathrm{L}$ of TBE solution were mixed in the testing wells. The reaction was initiated by adding $10 \mu \mathrm{L}$ of arachidonic acid substrate solution to all of the wells. All of the testing wells were then placed on a shaker for $5 \mathrm{~min}$, and $90 \mu \mathrm{L}$ of chromogen was then added to each well to stop the enzyme catalysis and develop the reaction. The absorbance of hydroperoxides produced by 15-LOX from arachidonic acid was measured at $490 \mathrm{~nm}$ using a microplate reader (Bio Tek Instruments, Tokyo, Japan).

\subsection{Cell Culture and Treatment}

The human monocytic cell line THP-1 was obtained from the RIKEN Cell Bank (Ibaraki, Japan) and cultured in RPMI-1640 medium supplemented with $10 \% \mathrm{FBS}, 100 \mathrm{U} / \mathrm{mL}$ penicillin, and $100 \mu \mathrm{g} / \mathrm{mL}$ streptomycin at $37{ }^{\circ} \mathrm{C}$ and $5 \% \mathrm{CO}_{2}$. THP-1 cells were induced with $100 \mathrm{nM}$ PMA for $48 \mathrm{~h}$ for differentiation into macrophages. THP-1 macrophages were treated with $25-100 \mu \mathrm{g} / \mathrm{mL}$ TBE for a maximum of $24 \mathrm{~h}$. We confirmed that TBE did not affect cell viability under these conditions by MTT assay.

\subsection{Real-Time RT-PCR}

Total cellular RNA was extracted using the total RNA extract reagent RNAiso Plus (Takara Bio, Shiga, Japan). We reverse-transcribed first-stand complementary DNAs from $2 \mu \mathrm{g}$ of the total RNA by using a High Capacity cDNA Reverse Transcription Kit (Applied Biosystems, Foster City, CA, USA). A real-time polymerase chain reaction (PCR) was performed on an ABI 7300 cycler (Applied Biosystems) with Power SYBR Green PCR mix (Applied Biosystems). The results are expressed as the copy number ratio of the target mRNAs to GAPDH mRNA. The primer sequences used for the analysis of tumor necrosis factor-alpha (TNF- $\alpha$ ) (TNF), interleukin-1beta (IL-1 $\beta)$ (IL1B), class A scavenger receptor (SR-A) (MSR1), CD36 (CD36), and lectin-like oxidized LDL receptor-1 (LOX-1) (OLR1) are shown in Table 1. 
Table 1. Primer sequences used for the analysis of TNF, IL1B, MSR1, CD36, OLR1 and GAPDH.

\begin{tabular}{ll}
\hline Gene & Sequence $\left(\mathbf{5}^{\prime}\right.$ to $\mathbf{3}^{\prime}$ ) \\
\hline \multirow{2}{*}{ TNF } & Forward: TGGAGAAGGGTGACCGACTC \\
& Reverse: TCCTCACAGGGCAATGATCC \\
IL1B & Forward: CTGTACGATCACTGAACTGC \\
& Reverse: CACCACTTGTTGCTCCATACT \\
MSR1 & Forward: AGGCCCTCTTAAGATCAGG \\
& Reverse: ACAACACGGGAACCAAAGTC \\
CD36 & Forward: CAATTAAAAAGCAAGTTGTCCTCGA \\
& Reverse: ATCACTTCCTGTGGATTTTGA \\
OLR1 & Forward: ACAGATCTCAGCCCGGCAACAAGCA \\
& Reverse: GGGAGACAGCGCCTCGGACTCTAAAT \\
GAPDH & Forward: TGCACCACCAACTGCTTAGC \\
& Reverse: GGCATGGACTGTGGTCATGAG \\
\hline
\end{tabular}

\subsection{Detection of MMP-9 Activity by Gelatin Zymography}

We assessed the gelatinolytic activity of MMP-9 by performing a gelatin zymography assay, as described in [24]. First, $5 \mu \mathrm{L}$ of culture supernatants were electrophoresed in $10 \%$ polyacrylamide gels containing $1 \%$ sodium dodecyl sulfate (SDS) and $0.1 \%$ gelatin. The gels were washed twice in $2.5 \%$ Triton $\mathrm{X}-100$ for $30 \mathrm{~min}$ and incubated overnight at $37^{\circ} \mathrm{C}$ in incubation buffer containing $50 \mathrm{mM}$ Tris- $\mathrm{HCl}$ (pH 7.5), $150 \mathrm{mM} \mathrm{NaCl}, 10 \mathrm{mM} \mathrm{CaCl}$, and $1 \mathrm{nM} \mathrm{ZnCl}_{2}$. The gels were then stained in $0.25 \%$ Coomassie brilliant blue R-250 and destained using 35\% ethanol and 10\% acetic acid solution. Gelatinolytic activity was quantified by scanning densitometry with an ImageQuant LAS-4000 biomolecular imaging system (Fujifilm, Tokyo, Japan) and analyzed by Multi Gauge software, ver. 3.0 (Fujifilm).

\subsection{Measurement of Intracellular ROS Production}

We measured intracellular ROS production by using DCFH-DA as the fluorescent probe. THP-1 macrophages were incubated with $20 \mu \mathrm{M}$ DCFH-DA/HBSS for $30 \mathrm{~min}$, then treated with $25-100 \mu \mathrm{g} / \mathrm{mL}$ TBE in fresh HBSS for $2 \mathrm{~h}$. The fluorescent intensity was detected at $485 \mathrm{~nm}$ excitation and $528 \mathrm{~nm}$ emission with the use of a microplate reader.

\subsection{Statistical Analysis}

All results are presented as mean \pm standard deviation (SD). We performed a one-way analysis of variance (ANOVA) followed by Tukey's post hoc test to compare treatment groups. Differences were considered significant when $p<0.05$. We used the GraphPad Prism 5 software package (GraphPad Software, La Jolla, CA, USA) for all of the statistical analyses.

\section{Results}

\subsection{The Total Polyphenol Content of TBE}

The total polyphenol content of the TBE powder measured by the Folin-Ciocalteu assay was $231 \pm 11 \mathrm{mg} / \mathrm{g}$. According to the high-performance liquid chromatography (HPLC) analyses of the TBE stock solution conducted by the supplier (Toyo Shinyaku), the contents of gallic acid and ellagic acid were calculated to be $115 \mathrm{mg} / \mathrm{g}$ and $4 \mathrm{mg} / \mathrm{g}$, respectively, suggesting that gallic acid is the major polyphenolic compound of TBE.

\subsection{The DPPH Radical Scavenging Activity of TBE}

The DPPH assay is based on the scavenging of the DPPH radical from the antioxidants, which produces a decrease in absorbance at $516 \mathrm{~nm}$. The results of DPPH radical scavenging activity of 
TBE and the reference antioxidant (+)-catechin are presented in Figure 1. TBE showed DPPH radical scavenging activity: the $\mathrm{EC}_{50}$ value (the concentration reducing DPPH absorbance by $50 \%$ ) was $7.2 \pm 1.2 \mu \mathrm{g} / \mathrm{mL}$.

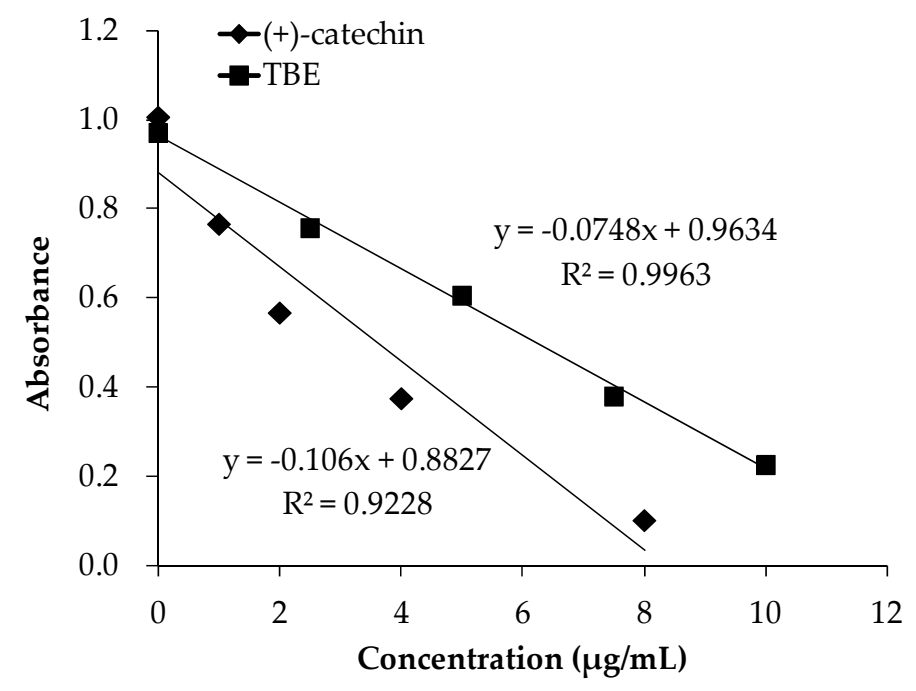

Figure 1. Decreases in the absorbance of 1,1-diphenyl-2-picrylhydrazyl (DPPH) radical at $516 \mathrm{~nm}$, measured after $20 \mathrm{~min}$ at $37^{\circ} \mathrm{C}$, depending on the concentration of (+)-catechin and TBE solution.

\subsection{TBE Slowed LDL Oxidation In Vitro}

To evaluate the antioxidant effect of TBE on LDL oxidation, we performed an LDL lag time assay. As shown in Figure 2, TBE significantly prolonged the LDL oxidation lag time $(1.25 \mu \mathrm{g} / \mathrm{mL}$ : $39.3 \pm 3.7 \mathrm{~min} ; 2.5 \mu \mathrm{g} / \mathrm{mL}: 58.6 \pm 5.6 \mathrm{~min}$; and control: $20.1 \pm 2.9 \mathrm{~min}$ ).

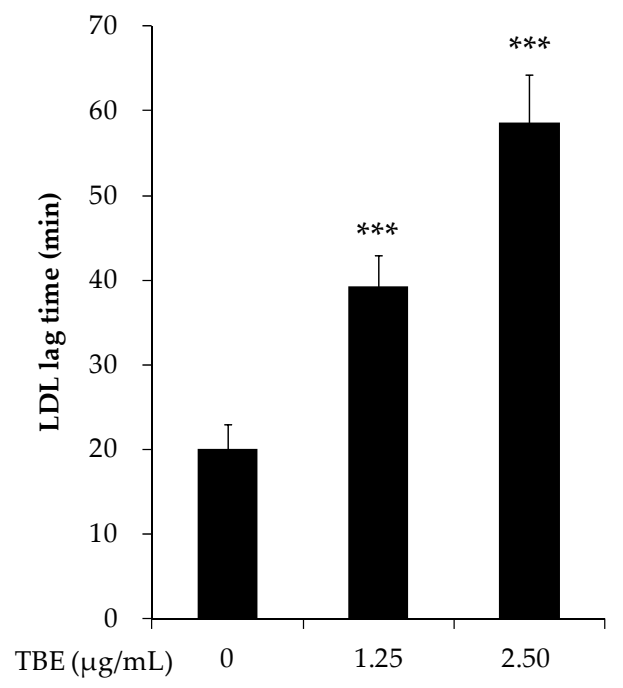

Figure 2. Effect of Terminalia bellirica extract (TBE) on low-density lipoprotein (LDL) oxidation lag time. LDL $(70 \mu \mathrm{g} / \mathrm{mL}$ protein) was incubated with $400 \mu \mathrm{M}$ of 2,2-azobis-4-methoxy-2,4-dimethylvaleronitrile $\left(\mathrm{AMVN}-\mathrm{CH}_{3} \mathrm{O}\right)$ in the absence or presence of TBE at $37^{\circ} \mathrm{C}$. The lag time for LDL oxidation was defined as the time interval between the initiation and intercept of the 2 tangents drawn to the lag and propagation phase of the absorbance curve at $234 \mathrm{~nm}$. Values are means $\pm \operatorname{SD}(n=5) .{ }^{* * *} p<0.001$, compared to untreated control group. 


\subsection{TBE Inhibited 15-Lipoxygenase (15-LOX) Activity}

In order to test the ability of TBE to directly inhibit 15-LOX, a cell-free assay using soybean 15-LOX enzyme and arachidonic acid as the substrate was applied. TBE displayed 15-LOX inhibitory activity compared to the solvent control (100 $\mu \mathrm{g} / \mathrm{mL}: 82.1 \% \pm 1.7 \% ; 200 \mu \mathrm{g} / \mathrm{mL}: 70.6 \% \pm 4.8 \% ; 400 \mu \mathrm{g} / \mathrm{mL}$ : $58.1 \% \pm 2.2 \%$ ) (Figure 3).

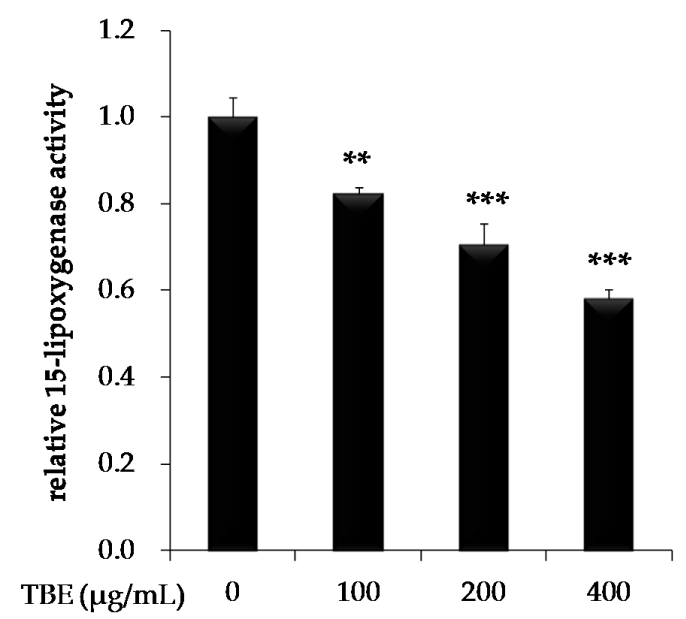

Figure 3. Effect of TBE on 15-lipoxygenase (15-LOX) activity. 15-LOX was mixed with arachidonic acid in the absence or presence of TBE. The absorbance of hydroperoxides produced by 15-LOX from arachidonic acid was measured at $490 \mathrm{~nm}$. Values are means $\pm \operatorname{SD}(n=3) .{ }^{* *} p<0.01,{ }^{* * *} p<0.001$, compared to untreated control group.

\subsection{TBE Reduced the mRNA Expression of TNF- $\alpha$ and IL-1 $\beta$ in THP-1 Macrophages}

Since the expression of inflammatory cytokines is a well-known response to inflammation in macrophages, we examined the effects of TBE on the mRNA expression of TNF- $\alpha$ and IL- $1 \beta$. Figure 4 shows that treatment with TBE $(100 \mu \mathrm{g} / \mathrm{mL})$ significantly reduced the mRNA expression of these genes.

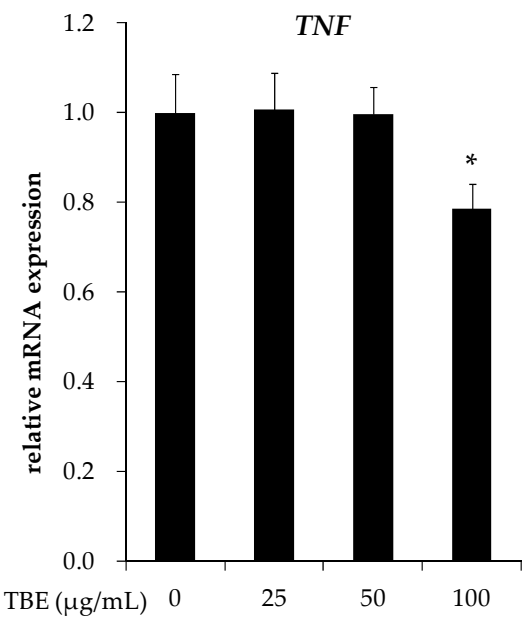

(A)

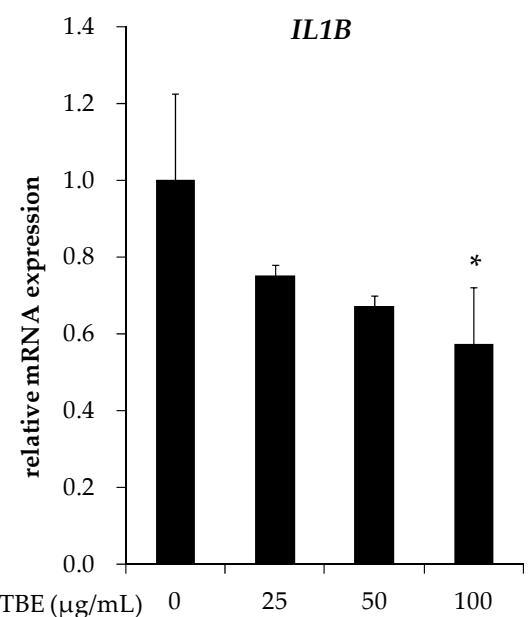

(B)

Figure 4. Effect of TBE on the mRNA expression of pro-inflammatory cytokines in macrophages. THP-1 macrophages were incubated with 25-100 $\mu \mathrm{g} / \mathrm{mL}$ TBE for $24 \mathrm{~h}$. TNF (A) and IL1B (B) mRNA expressions were measured by real-time RT-PCR. Values are means $\pm \mathrm{SD}(n=3) .{ }^{*} p<0.05$, compared to untreated control group. 


\subsection{TBE Suppressed the mRNA Expression of LOX-1 in THP-1 Macrophages}

It has been reported that SR-A, CD36, and LOX-1 play a critical role during lipid accumulation in macrophages. We examined the effects of TBE on the mRNA expression of these scavenger receptors. Incubation with TBE $(100 \mu \mathrm{g} / \mathrm{mL})$ significantly suppressed the mRNA expression of LOX-1 without affecting the expression of SR-A and CD36 (Figure 5).

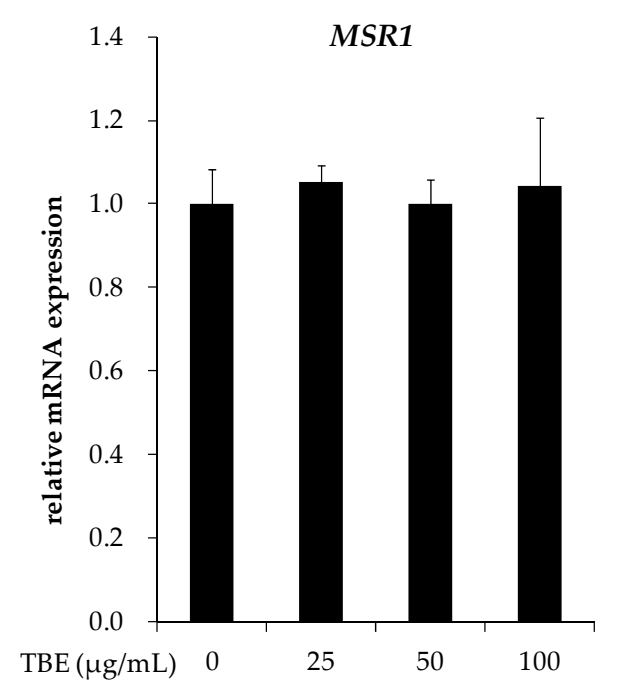

(A)

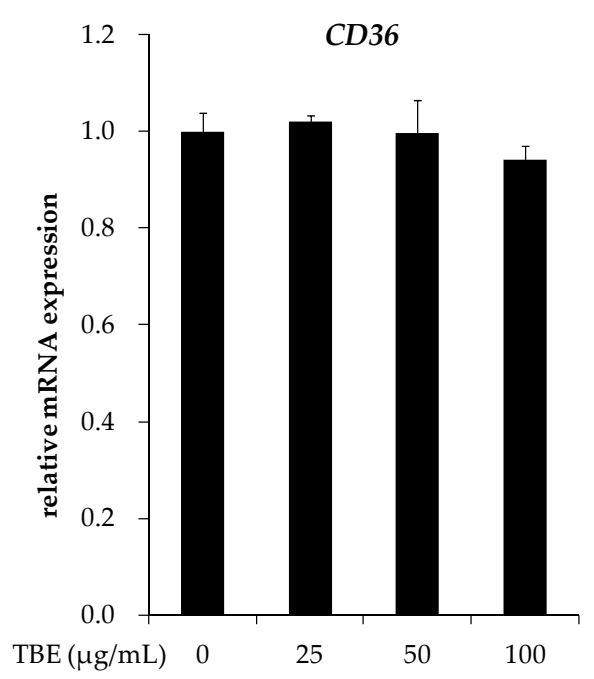

(B)

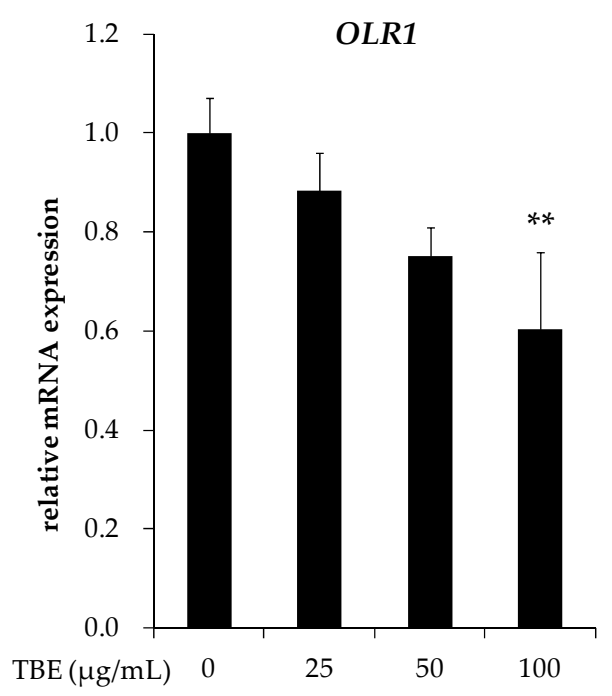

(C)

Figure 5. Effect of TBE on the mRNA expression of scavenger receptors in macrophages. THP-1 macrophages were incubated with 25-100 $\mu \mathrm{g} / \mathrm{mL}$ TBE for $24 \mathrm{~h}$. MSR1 (A), CD36 (B) and OLR1 (C) mRNA expressions were measured by real-time RT-PCR. Values are means $\pm \operatorname{SD}(n=3)$. ${ }^{* *} p<0.01$, compared to untreated control group.

\subsection{TBE Reduced the MMP-9 Secretion in THP-1 Macrophages}

MMP-9 induces atherosclerotic plaque rupture, and its expression is strongly correlated with lesion instability and the manifestation of atherosclerosis. To clarify the effect of TBE on MMP-9 activation in macrophages, we analyzed the secretion level of MMP-9 by conducting a gelatin zymography assay. Treatment with TBE $(100 \mu \mathrm{g} / \mathrm{mL})$ significantly reduced the MMP-9 secretion (Figure 6). 


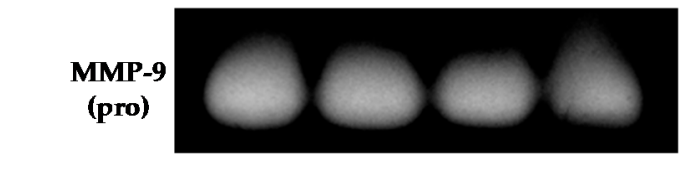

$\mathrm{TBE}(\mu \mathrm{g} / \mathrm{mL}) \quad 0 \quad 25 \quad 50 \quad 100$

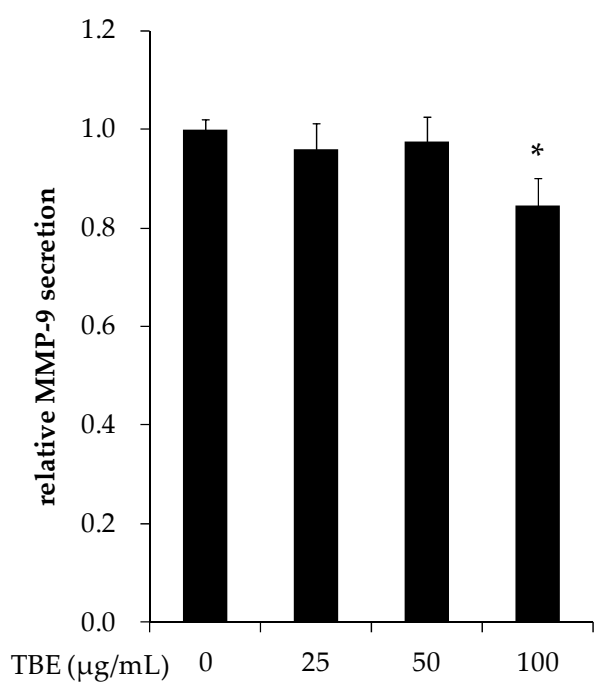

(B)

Figure 6. Effect of TBE on matrix metalloproteinase (MMP)-9 secretion in macrophages. THP-1 macrophages were incubated with $25-100 \mu \mathrm{g} / \mathrm{mL}$ TBE for $24 \mathrm{~h}$. MMP-9 secretion in culture supernatants (A) and its quantification (B) were analyzed by gelatin zymography. Values are means $\pm \mathrm{SD}(n=3) .{ }^{*} p<0.05$, compared to untreated control group.

\subsection{TBE Decreased the ROS Production in THP-1 Macrophages}

ROS play an important role in inflammatory mediator expression. To examine whether TBE exerted an anti-inflammatory effect by the downregulation of ROS production, we measured the intracellular ROS production in THP-1 macrophages by using DCFH-DA. As shown in Figure 7, incubation with TBE significantly decreased the ROS production in a dose-dependent manner.

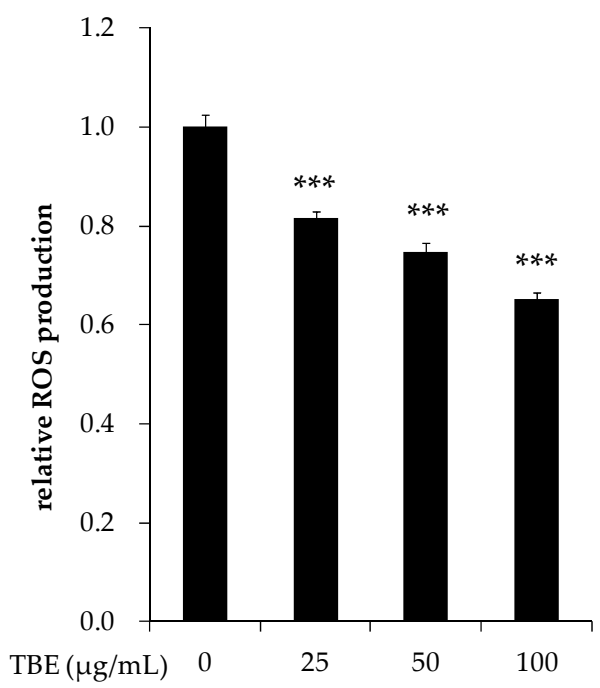

Figure 7. Effect of TBE on reactive oxygen species (ROS) production in macrophages. THP-1 macrophages were incubated with 25-100 $\mathrm{g} / \mathrm{mL}$ TBE for $2 \mathrm{~h}$, and then intracellular ROS levels were measured by using $2^{\prime}, 7^{\prime}$-dichlorofluorescein-diacetate (DCFH-DA) (excitation $485 \mathrm{~nm} /$ emission $528 \mathrm{~nm})$. Values are means $\pm \operatorname{SD}(n=3) .{ }^{* * *} p<0.001$, compared to untreated control group. 


\section{Discussion}

The oxidative modification of LDL plays an important role in the initiation and progression of atherosclerosis, inducing not only foam cell formation but also an inflammatory response. Lipid hydroperoxide and lysophosphatidylcholine, components of oxLDL, are known to increase the expression of adhesion molecules and growth factors, apoptosis, and the dysfunction of endothelial nitric oxide synthase in the vascular wall $[25,26]$. The release of pro-inflammatory cytokines and MMPs from macrophages is also promoted in the presence of oxLDL [27]. LDL oxidation results from various mechanisms, such as free radicals, active metal ions, and peroxidative enzymes including lipoxygenase and myeloperoxidase [28]. In the present study, we demonstrated that TBE contained polyphenols and showed DPPH radical scavenging activity. The fruit of Terminalia bellirica is known to contain several types of polyphenols (e.g., gallic acid, ellagic acid) [2]. Middha et al. [29] reported that gallic acid and ellagic acid had free radical scavenging activity and inhibited lipid peroxidation. In the present study, TBE significantly prolonged the LDL oxidation lag time, indicating the inhibition of the free radical-induced lipid peroxidation of LDL. We also observed that TBE displayed 15-lipoxygenase inhibitory activity. Some polyphenols (e.g., gallic acid, gallic acid glycoside) have been shown to inhibit lipoxygenase activity and lipoxygenase-mediated LDL lipid peroxidation [30,31]. These findings suggest that TBE may exert an antioxidant effect on LDL oxidation via the inhibition of both the radical reaction by free radicals and the non-radical reaction by peroxidative enzymes.

Macrophage-mediated inflammation is a well-known key step in atherosclerosis progression. Macrophages express scavenger receptors and secrete a number of cytokines and MMPs, which contribute to lesion progression, endothelial dysfunction, and plaque rupture. The inhibition of these inflammatory mediators would thus be useful for the control of inflammation. In the present study, TBE suppressed the expression of pro-inflammatory cytokines, LOX-1, MMP-9, and ROS production in THP-1 macrophages.

Pro-inflammatory cytokines such as TNF- $\alpha$, IL-1 $\beta$, and IL- 6 are produced by activated macrophages and involved in the upregulation of the inflammatory response. TNF- $\alpha$ and IL-1 $\beta$ are considered key inflammatory cytokines associated with many inflammatory processes, including the expression of adhesion molecules and other cytokines [32]. We found that TBE reduced the mRNA expression of TNF- $\alpha$ and IL- $1 \beta$ in THP-1 macrophages. The deficiency of TNF and IL- 1 has been shown to decrease the atherosclerotic lesion size in $\mathrm{apoE}^{-/-}$mice $[33,34]$.

Scavenger receptors are implicated in the uptake of oxLDL and foam cell formation in macrophages. Here, we showed that TBE suppressed the mRNA expression of LOX-1 without altering the expression of SR-A and CD36. LOX-1 is a major receptor for oxLDL, and its expression is enhanced in several disease states including diabetes, hypertension, and atherosclerosis [35]. Inoue et al. [36] demonstrated that the overexpression of LOX-1 induced foam cell accumulation and atherosclerotic lesion formation in $\mathrm{apoE}^{-/-}$mice. In other studies, LOX-1 deletion resulted in a significant attenuation of the atherosclerosis plaque progression and inflammatory response [37,38]. The expression of LOX-1 is known to be upregulated by pro-inflammatory cytokines, oxLDL, and free radicals, suggesting its critical role for inflammation and the development of atherosclerosis [39,40]. In view of the function of LOX-1, the suppression of LOX-1 expression by TBE may contribute to the amelioration of foam cell formation and inflammation. Additionally, our present findings revealed that TBE slowed LDL oxidation in vitro. These data suggest that TBE can inhibit the generation and uptake of oxLDL.

MMPs released from macrophages participate in unstable plaque rupture, and high amounts of MMPs are found in macrophage-rich lesions of atherosclerotic plaque [10]. The present study's results demonstrated that TBE inhibited the secretion of MMP-9 in THP-1 macrophages. MMP-9 is synthesized as a pro-form containing a pre-domain that is removed during activation. Further, modified LDL and pro-inflammatory cytokines are known to stimulate the expression and activation of MMP-9 [41,42]. Our results indicate that TBE may reduce matrix degradation, which could improve lesion stability. 
ROS have been shown to play a well-established role in the inflammatory response. In an earlier study, the mRNA expression of pro-inflammatory cytokines in macrophages was inhibited by a ROS inhibitor, suggesting an important role for ROS in inflammatory mediator production [43]. Our present findings showed that TBE decreased the ROS production in THP-1 macrophages. ROS are generated from several sources, such as NADPH oxidase, mitochondrial respiration, and the metabolism of arachidonic acid [44]. To induce monocyte-to-macrophage differentiation, we stimulated THP-1 cells with PMA, which activates NADPH oxidase mediated by protein kinase C (PKC) [45]. It is unclear whether TBE suppressed ROS production by inhibiting the enzymes involved in ROS production or by scavenging ROS. However, the antioxidant activity of TBE is likely to account at least in part for the decrease in ROS production.

ROS have been known to activate multiple signaling pathways and transcription factors, including MAP kinases (MAPKs), PI3K/Akt, PKC, and nuclear factor- $\mathrm{B}$ (NF-kB), all of which mediate inflammatory gene transcription $[13,46]$. It was reported that the inhibition of NADPH oxidase activity and ROS generation reduced MAPKs phosphorylation and the subsequent inflammatory mediator expression [43,47]. A genetic deficiency of NADPH oxidase diminished serum inflammatory markers and atherosclerotic lesion formation in mice [48,49]. Several polyphenols (i.e., gallic acid, resveratrol, and epigallocatechin) were shown to inhibit inflammatory mediator expression via the suppression of ROS/MAPKs/NF-kB pathway [18,50], supporting our hypothesis that TBE might inhibit the expression of TNF- $\alpha$, IL-1 $\beta$, LOX-1, and MMP-9 due partly to its antioxidant activity.

\section{Conclusions}

In conclusion, TBE exerted an inhibitory effect on LDL oxidation and inhibited pro-inflammatory cytokines and LOX-1 expression, MMP-9 secretion, and ROS production in macrophages. Our results suggest that TBE may be effective in the reduction of atherosclerosis risk factors, but more research is needed to clarify the molecular mechanisms and functions of TBE.

Acknowledgments: This study was supported in part by JSPS KAKENHI (Grant No. 23240104). We also thank all members of the Kondo Laboratory (Ochanomizu University) for the valuable discussions.

Author Contributions: Miori Tanaka, Yoshimi Kishimoto, and Kazuo Kondo conceived and designed the experiments; Miori Tanaka performed the experiments with assistance from Emi Saita, Norie Suzuki-Sugihara, and Chie Taguchi; Tomoyasu Kamiya contributed materials and HPLC analysis; Miori Tanaka and Yoshimi Kishimoto wrote the paper. Kaoruko Iida and Kazuo Kondo supervised the study and reviewed the manuscript. All authors have read and approved the final manuscript.

Conflicts of Interest: The authors declare no conflict of interest.

\section{References}

1. Modak, M.; Dixit, P.; Londhe, J.; Ghaskadbi, S.; Devasagayam, T.P. Indian herbs and herbal drugs used for the treatment of diabetes. J. Clin. Biochem. Nutr. 2007, 40, 163-173. [CrossRef] [PubMed]

2. Pfundstein, B.; El Desouky, S.K.; Hull, W.E.; Haubner, R.; Erben, G.; Owen, R.W. Polyphenolic compounds in the fruits of egyptian medicinal plants (Terminalia bellerica, Terminalia chebula and Terminalia horrida): Characterization, quantitation and determination of antioxidant capacities. Phytochemistry 2010, 71, 1132-1148. [CrossRef] [PubMed]

3. Shaila, H.P.; Udupa, S.L.; Udupa, A.L. Hypolipidemic activity of three indigenous drugs in experimentally induced atherosclerosis. Int. J. Cardiol. 1998, 67, 119-124. [CrossRef]

4. Makihara, H.; Shimada, T.; Machida, E.; Oota, M.; Nagamine, R.; Tsubata, M.; Kinoshita, K.; Takahashi, K.; Aburada, M. Preventive effect of Terminalia bellirica on obesity and metabolic disorders in spontaneously obese type 2 diabetic model mice. J. Nat. Med. 2012, 66, 459-467. [CrossRef] [PubMed]

5. Khan, A.; Gilani, A. Pharmacodynamic evaluation of Terminalia bellerica for its antihypertensive effect. J. Food Drug Anal. 2008, 16, 6-14.

6. Kaplan, M.; Aviram, M. Oxidized low density lipoprotein: Atherogenic and proinflammatory characteristics during macrophage foam cell formation. An inhibitory role for nutritional antioxidants and serum paraoxonase. Clin. Chem. Lab. Med. 1999, 37, 777-787. [CrossRef] [PubMed] 
7. Chistiakov, D.A.; Bobryshev, Y.V.; Orekhov, A.N. Macrophage-mediated cholesterol handling in atherosclerosis. J. Cell. Mol. Med. 2016, 20, 17-28. [CrossRef] [PubMed]

8. Burchardt, P.; Zurawski, J.; Zuchowski, B.; Kubacki, T.; Murawa, D.; Wiktorowicz, K.; Wysocki, H. Low-density lipoprotein, its susceptibility to oxidation and the role of lipoprotein-associated phospholipase A2 and carboxyl ester lipase lipases in atherosclerotic plaque formation. Arch. Med. Sci. AMS 2013, 9, 151-158. [CrossRef] [PubMed]

9. Libby, P. Inflammation in atherosclerosis. Nature 2002, 420, 868-874. [CrossRef] [PubMed]

10. Galis, Z.S.; Sukhova, G.K.; Lark, M.W.; Libby, P. Increased expression of matrix metalloproteinases and matrix degrading activity in vulnerable regions of human atherosclerotic plaques. J. Clin. Investig. 1994, 94, 2493-2503. [CrossRef] [PubMed]

11. Thannickal, V.J.; Fanburg, B.L. Reactive oxygen species in cell signaling. Am. J. Physiol. Lung Cell. Mol. Physiol. 2000, 279, L1005-L1028. [PubMed]

12. Droge, W. Free radicals in the physiological control of cell function. Physiol. Rev. 2002, 82, 47-95. [CrossRef] [PubMed]

13. Mittal, M.; Siddiqui, M.R.; Tran, K.; Reddy, S.P.; Malik, A.B. Reactive oxygen species in inflammation and tissue injury. Antioxid. Redox Signal. 2014, 20, 1126-1167. [CrossRef] [PubMed]

14. Chen, F.; Eriksson, P.; Hansson, G.K.; Herzfeld, I.; Klein, M.; Hansson, L.O.; Valen, G. Expression of matrix metalloproteinase 9 and its regulators in the unstable coronary atherosclerotic plaque. Int. J. Mol. Med. 2005, 15, 57-65. [CrossRef] [PubMed]

15. Watanabe, N.; Ikeda, U. Matrix metalloproteinases and atherosclerosis. Curr. Atheroscler. Rep. 2004, 6, 112-120. [CrossRef] [PubMed]

16. Frankel, E.N.; Kanner, J.; German, J.B.; Parks, E.; Kinsella, J.E. Inhibition of oxidation of human low-density lipoprotein by phenolic substances in red wine. Lancet 1993, 341, 454-457. [CrossRef]

17. Miura, S.; Watanabe, J.; Sano, M.; Tomita, T.; Osawa, T.; Hara, Y.; Tomita, I. Effects of various natural antioxidants on the $\mathrm{Cu}^{2+}$-mediated oxidative modification of low density lipoprotein. Biol. Pharm. Bull. 1995, 18, 1-4. [CrossRef] [PubMed]

18. Rahman, I.; Biswas, S.K.; Kirkham, P.A. Regulation of inflammation and redox signaling by dietary polyphenols. Biochem. Pharmacol. 2006, 72, 1439-1452. [CrossRef] [PubMed]

19. Hertog, M.G.; Feskens, E.J.; Hollman, P.C.; Katan, M.B.; Kromhout, D. Dietary antioxidant flavonoids and risk of coronary heart disease: The zutphen elderly study. Lancet 1993, 342, 1007-1011. [CrossRef]

20. Knekt, P.; Jarvinen, R.; Reunanen, A.; Maatela, J. Flavonoid intake and coronary mortality in finland: A cohort study. BMJ 1996, 312, 478-481. [CrossRef] [PubMed]

21. Huxley, R.R.; Neil, H.A. The relation between dietary flavonol intake and coronary heart disease mortality: A meta-analysis of prospective cohort studies. Eur. J. Clin. Nutr. 2003, 57, 904-908. [CrossRef] [PubMed]

22. Ainsworth, E.A.; Gillespie, K.M. Estimation of total phenolic content and other oxidation substrates in plant tissues using folin-ciocalteu reagent. Nat. Protoc. 2007, 2, 875-877. [CrossRef] [PubMed]

23. Hirano, R.; Kondo, K.; Iwamoto, T.; Igarashi, O.; Itakura, H. Effects of antioxidants on the oxidative susceptibility of low-density lipoprotein. J. Nutr. Sci. Vitaminol. 1997, 43, 435-444. [CrossRef] [PubMed]

24. Kishimoto, Y.; Tani, M.; Uto-Kondo, H.; Iizuka, M.; Saita, E.; Sone, H.; Kurata, H.; Kondo, K. Astaxanthin suppresses scavenger receptor expression and matrix metalloproteinase activity in macrophages. Eur. J. Nutr. 2010, 49, 119-126. [CrossRef] [PubMed]

25. Kume, N.; Cybulsky, M.I.; Gimbrone, M.A., Jr. Lysophosphatidylcholine, a component of atherogenic lipoproteins, induces mononuclear leukocyte adhesion molecules in cultured human and rabbit arterial endothelial cells. J. Clin. Investig. 1992, 90, 1138-1144. [CrossRef] [PubMed]

26. Kume, N.; Gimbrone, M.A., Jr. Lysophosphatidylcholine transcriptionally induces growth factor gene expression in cultured human endothelial cells. J. Clin. Investig. 1994, 93, 907-911. [CrossRef] [PubMed]

27. Rajavashisth, T.B.; Liao, J.K.; Galis, Z.S.; Tripathi, S.; Laufs, U.; Tripathi, J.; Chai, N.N.; Xu, X.P.; Jovinge, S.; Shah, P.K.; et al. Inflammatory cytokines and oxidized low density lipoproteins increase endothelial cell expression of membrane type 1-matrix metalloproteinase. J. Biol. Chem. 1999, 274, 11924-11929. [CrossRef] [PubMed]

28. Yoshida, H.; Kisugi, R. Mechanisms of LDL oxidation. Clin. Chim. Acta Int. J. Clin. Chem. 2010, 411, 1875-1882. [CrossRef] [PubMed] 
29. Middha, S.K.; Goyal, A.K.; Lokesh, P.; Yardi, V.; Mojamdar, L.; Keni, D.S.; Babu, D.; Usha, T. Toxicological evaluation of emblica officinalis fruit extract and its anti-inflammatory and free radical scavenging properties. Pharmacogn. Mag. 2015, 11, S427-S433. [PubMed]

30. Eshwarappa, R.S.; Ramachandra, Y.L.; Subaramaihha, S.R.; Subbaiah, S.G.; Austin, R.S.; Dhananjaya, B.L. Anti-lipoxygenase activity of leaf gall extracts of Terminalia chebula (gaertn.) retz. (combretaceae). Pharmacogn. Res. 2016, 8, 78-82. [CrossRef]

31. Ngoc, T.M.; Hung, T.M.; Thuong, P.T.; Kim, J.C.; Choi, J.S.; Bae, K.; Hattori, M.; Choi, C.S.; Lee, J.S.; Min, B.S. Antioxidative activities of galloyl glucopyranosides from the stem-bark of juglans mandshurica. Biosci. Biotechnol. Biochem. 2008, 72, 2158-2163. [CrossRef] [PubMed]

32. Ait-Oufella, H.; Taleb, S.; Mallat, Z.; Tedgui, A. Recent advances on the role of cytokines in atherosclerosis. Arterioscler. Thromb. Vasc. Biol. 2011, 31, 969-979. [CrossRef] [PubMed]

33. Ohta, H.; Wada, H.; Niwa, T.; Kirii, H.; Iwamoto, N.; Fujii, H.; Saito, K.; Sekikawa, K.; Seishima, M. Disruption of tumor necrosis factor-alpha gene diminishes the development of atherosclerosis in ApoE-deficient mice. Atherosclerosis 2005, 180, 11-17. [CrossRef] [PubMed]

34. Merhi-Soussi, F.; Kwak, B.R.; Magne, D.; Chadjichristos, C.; Berti, M.; Pelli, G.; James, R.W.; Mach, F.; Gabay, C. Interleukin-1 plays a major role in vascular inflammation and atherosclerosis in male apolipoprotein E-knockout mice. Cardiovasc. Res. 2005, 66, 583-593. [CrossRef] [PubMed]

35. Pirillo, A.; Norata, G.D.; Catapano, A.L. LOX-1, OxLDL, and atherosclerosis. Mediat. Inflamm. 2013. [CrossRef] [PubMed]

36. Inoue, K.; Arai, Y.; Kurihara, H.; Kita, T.; Sawamura, T. Overexpression of lectin-like oxidized low-density lipoprotein receptor-1 induces intramyocardial vasculopathy in apolipoprotein E-null mice. Circ. Res. 2005, 97, 176-184. [CrossRef] [PubMed]

37. Mehta, J.L.; Sanada, N.; Hu, C.P.; Chen, J.; Dandapat, A.; Sugawara, F.; Satoh, H.; Inoue, K.; Kawase, Y.; Jishage, K.; et al. Deletion of LOX-1 reduces atherogenesis in LDLR knockout mice fed high cholesterol diet. Circ. Res. 2007, 100, 1634-1642. [CrossRef] [PubMed]

38. Honjo, M.; Nakamura, K.; Yamashiro, K.; Kiryu, J.; Tanihara, H.; McEvoy, L.M.; Honda, Y.; Butcher, E.C.; Masaki, T.; Sawamura, T. Lectin-like oxidized LDL receptor-1 is a cell-adhesion molecule involved in endotoxin-induced inflammation. Proc. Natl. Acad. Sci. USA 2003, 100, 1274-1279. [CrossRef] [PubMed]

39. Xu, S.; Ogura, S.; Chen, J.; Little, P.J.; Moss, J.; Liu, P. LOX-1 in atherosclerosis: Biological functions and pharmacological modifiers. Cell. Mol. Life Sci. CMLS 2013, 70, 2859-2872. [CrossRef] [PubMed]

40. Pirillo, A.; Uboldi, P.; Ferri, N.; Corsini, A.; Kuhn, H.; Catapano, A.L. Upregulation of lectin-like oxidized low density lipoprotein receptor 1 (LOX-1) expression in human endothelial cells by modified high density lipoproteins. Biochem. Biophys. Res. Commun. 2012, 428, 230-233. [CrossRef] [PubMed]

41. Radhika, A.; Jacob, S.S.; Sudhakaran, P.R. Influence of oxidatively modified LDL on monocyte-macrophage differentiation. Mol. Cell. Biochem. 2007, 305, 133-143. [CrossRef] [PubMed]

42. Nissinen, L.; Kahari, V.M. Matrix metalloproteinases in inflammation. Biochim. Biophys. Acta 2014, 1840, 2571-2580. [CrossRef] [PubMed]

43. Hsu, H.Y.; Wen, M.H. Lipopolysaccharide-mediated reactive oxygen species and signal transduction in the regulation of interleukin-1 gene expression. J. Biol. Chem. 2002, 277, 22131-22139. [CrossRef] [PubMed]

44. Pendyala, S.; Usatyuk, P.V.; Gorshkova, I.A.; Garcia, J.G.; Natarajan, V. Regulation of NADPH oxidase in vascular endothelium: The role of phospholipases, protein kinases, and cytoskeletal proteins. Antioxid. Redox Signal. 2009, 11, 841-860. [CrossRef] [PubMed]

45. Chen, F.; Yu, Y.; Haigh, S.; Johnson, J.; Lucas, R.; Stepp, D.W.; Fulton, D.J. Regulation of NADPH oxidase 5 by protein kinase c isoforms. PLoS ONE 2014, 9, e88405. [CrossRef] [PubMed]

46. Lee, I.T.; Yang, C.M. Role of NADPH oxidase/ROS in pro-inflammatory mediators-induced airway and pulmonary diseases. Biochem. Pharmacol. 2012, 84, 581-590. [CrossRef] [PubMed]

47. Lee, I.T.; Luo, S.F.; Lee, C.W.; Wang, S.W.; Lin, C.C.; Chang, C.C.; Chen, Y.L.; Chau, L.Y.; Yang, C.M. Overexpression of HO-1 protects against TNF-alpha-mediated airway inflammation by down-regulation of TNFR1-dependent oxidative stress. Am. J. Pathol. 2009, 175, 519-532. [CrossRef] [PubMed]

48. Zhang, W.J.; Wei, H.; Frei, B. Genetic deficiency of NADPH oxidase does not diminish, but rather enhances, LPS-induced acute inflammatory responses in vivo. Free Radic. Biol. Med. 2009, 46, 791-798. [CrossRef] [PubMed] 
49. Barry-Lane, P.A.; Patterson, C.; van der Merwe, M.; Hu, Z.; Holland, S.M.; Yeh, E.T.; Runge, M.S. P47phox is required for atherosclerotic lesion progression in $\mathrm{ApoE}^{-/-}$mice. J. Clin. Investig. 2001, 108, 1513-1522. [CrossRef] [PubMed]

50. Yang, H.L.; Huang, P.J.; Liu, Y.R.; Kumar, K.J.; Hsu, L.S.; Lu, T.L.; Chia, Y.C.; Takajo, T.; Kazunori, A.; Hseu, Y.C. Toona sinensis inhibits LPS-induced inflammation and migration in vascular smooth muscle cells via suppression of reactive oxygen species and NF-кB signaling pathway. Oxid. Med. Cell. Longev. 2014. [CrossRef] [PubMed]

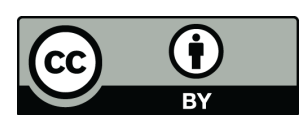

(c) 2016 by the authors; licensee MDPI, Basel, Switzerland. This article is an open access article distributed under the terms and conditions of the Creative Commons Attribution (CC-BY) license (http://creativecommons.org/licenses/by/4.0/). 